\title{
HIDROLISIS GUGUS METOKSIL PEKTIN AMPAS TEBU UNTUK MENGHASILKAN BIOMETANOL
}

\author{
Akyunul Jannah, S.Si, M.P dan drg.Arief Suryadinata
}

\begin{abstract}
ABSTRAK
Methanol is a potential in two areas, namely as fuel cells and biodiesel. Among the many biomass, pectin is one of the best for the production of methanol. The purpose of this study was to determine the influence of pectin methyl esterase enzyme concentration (PME) group metoksil rough on pectin hydrolysis of bagasse to produce the highest levels of biometanol.

Methods This study includes the preparation of the bagasse, further hydrolysis using crude extract of the enzyme pectin methyl esterase (PMEs) resulting from bacterial culture Bacillus subtilis at Borth Nutrient media (NB) with 1\% pectin. Hydrolysis of Metoksil groups of poligalakturonat acid in the pectin bagasse to obtain the concentration of methanol to vary the enzyme crude extract PMEs. Concentration of crude enzyme extract PMEs used was 10\%, 15\%, 20\% and 25\% in 24-hour incubation with 2 repetitions performed. The resulting methanol levels were analyzed using GC (Gas Chromatography).

The results of this study concluded that allowing the concentration used for hydrolysis of bagasse to produce methanol using crude enzyme from Bacillus subtilis (PMEs) is 10\% with a methanol content of $0.02 \%$
\end{abstract}

Keywords: Methanol, Bacillus subtilis, bagasse, PMEs and pectin

\section{A. PENDAhuluan}

Metanol sangat berpotensi dalam dua bidang yaitu sebagai sel bahan bakar dan biodiesel. Sehingga sangat penting untuk dilakukan penelitian bagaimana cara efektif menghasilkan metanol. Saat ini, sebagian besar metanol dibuat dari gas alam. Pada tahun 1997, 86\% metanol dihasilkan dari gas alam (Ohlström et al, 2001) yang merupakan sumber energi nonterbarukan yang semakin lama semakin habis. Sehingga diperlukan alternatif pengganti pembuat metanol dari bahan lain yaitu dari biomasa.

Di antara banyak biomassa, pektin adalah salah satu yang terbaik untuk produksi metanol. Penelitian yang dilakukan oleh Wang (2006) melaporkan kondisi optimum yang diperoleh pada pembuatan methanol dari ampas tebu menggunakan enzim
Pectin Metil Esterase murni. Pektin kaya akan sisi metoksil sehingga dapat diesterifikasi untuk menghasilkan metanol, dalam hal ini yang berperan dalam hidrolisis sisi metoksil pada pektin adalah Pectin Metil Esterase (PME). Enzim pektin metil esterase dihasilkan dari kutur bakteri Aspergillus niger (Bhat, 2000; Kashyap et al., 2001). Aspergillus awamori (Blandino et al., 2002), Aspergillus foetidus (Sebastian et al., 1996; Hours et al., 1988), Aspergillus japonicum (Semenova et al., 2003), Aspergillus carneus (El-Sheekh et al., 2009), Aspergillus flavus (Yadav et al., 2008) and Bacillus subtilis (Ahlawat et al., 2009).

Ampas tebu mengandung 55\% $62 \%$ pektin yang mengandung $9 \%$ $10 \%$ kelompok sisi metil. Kelompok 
Hidrolisis Gugus Metoksil Pektin Ampas Tebu Untuk ...

sisi metil ini adalah hasil dari esterifikasi dengan gugus asam karboksilat. Oleh karena itu, Hidrolisis dari kelompok ester ini akan menghasilkan metanol, sehingga ampas tebu merupakan sumber biomassa yang baik untuk produksi metanol menggunakan Pektin Metil Esterase.

Ketersediaan ampas tebu saat ini sangat melimpah, pemanfaatan sebagai bioetanol sudah mulai banyak dilakukan baik oleh peneliti maupun praktisi. Sedangkan pemanfaatan sebagai bahan baku methanol khususnya di Indonesia masih belum banyak dilakukan dan merujuk dari penelitian Wang (2006) penelitian ini bertujuan mengkaji pembuatan methanol dari ampas tebu menggunakan enzim Pektin Metil Esterase (PME) dengan kajian berbeda dari penelitian sebelumnya yaitu menggunakan PME dari Bacillus subtilis dengan variasi konsentrasi PME yang masih dalam bentuk crude enzim (kasar).

\section{Tujuan Penelitian}

Tujuan dari penelitian ini adalah: mengetahui pengaruh konsentrasi enzim pektin metil esterase (PME) kasar pada hidrolisis gugus metoksil pektin ampas tebu untuk menghasilkan kadar biometanol tertinggi.

\section{Manfaat Penelitian}

Penelitian ini diharapkan dapat memberikan inovasi energi alternatif sebagai pengganti energi bahan bakar fosil pada dunia, khususnya pada negara Indonesia yang mana semakin lama semakin berkurang, serta untuk meminimalisir produksi karbon monoksida (CO) yang dihasilkan dari proses pembakaran yang berakibat pada pemanasan global (efek rumah kaca). Juga alternatif pengolahan limbah dari pabrik gula khususnya ampas tebu menjadi produk yang berguna dan mempunyai nilai ekonomi yang cukup tinggi.

\section{B. METODE PENELITIAN}

1. Rancangan Penelitian

Penelitian ini bersifat eksperimental laboratorik. Sampel yang digunakan adalah ampas tebu hasil gilingan terakhir dari pabrik gula (PG) Kerebet Kabupaten Malang. Pertama dilakukan preparasi pada ampas, yaitu dengan pencucian senyawa non-pektin dengan menggunakan pelarut non-polar (etanol $96 \%$ dan aseton teknis) tujuannya untuk menghilangkan senyawa-senyawa residu yang terdapat pada ampas tebu. Selanjutnya dilakukan hidrolisis dalam tabung reaktor (erlenmeyer) dengan menggunakan ekstrak kasar enzim pektin metil esterase (PMEs) yang dihasilkan dari kultur bakteri Bacillus subtilis pada media Nutrien Borth (NB) dengan pektin $1 \%$.

Proses hidrolisis gugus metoksil asam poligalakturonat pada pektin ampas tebu untuk memperoleh metanol dilakukan variasi konsentrasi ekstrak kasar enzim PMEs. Konsentrasi ekstrak kasar enzim PMEs yang digunakan adalah $10 \%, 15 \%, 20 \%$ dan $25 \%$ pada inkubasi 24 jam dengan dilakukan 2 kali pengulangan. Kadar metanol yang dihasilkan dianalisis menggunakan KG (Kromatografi Gas).

\section{Pelaksanaan Penelitian}

Untuk tahap preparasi disini meliputi preparasi sampel, ekstraksi pektin ampas tebu dan preparasi media pertumbuhan Bacillus subtilis.
a. Preparasi Sampel
Untuk
proses
digunakan metode maserasi 
menggunakan pelarut etanol $96 \%$ sebanyak $500 \mathrm{~mL}$ dicampurkan dalam 30 gr ampas tebu. Proses maserasi dilakukan selama 30 menit dalam gelas beker $500 \mathrm{~mL}$. Kemudian ampas tebu disaring dengan penyaring vakum untuk memisahkan antara ampas tebu dan filtrat.

Filtrat yang dihasilkan dibuang sedangkan ampas tebu dibilas kembali menggunakan $300 \mathrm{~mL}$ etanol $96 \quad \%$ kemudian disaring menggunakan penyaring vakum. Pembilasan yang terakhir dilakukan dengan penambahan $300 \mathrm{~mL}$ aseton teknis dan disaring kembali mengunakan penyaring vakum (Ujejski, 1957).

\section{b. Ekstraksi Pektin Ampas Tebu}

Untuk ekstrak pektin ampas tebu dilakukan dengan menimbang $10 \mathrm{gr}$ ampas tebu hasil preparasi dengan ditambahkan $200 \mathrm{~mL}$ larutan $\mathrm{HCl}$ $0,05 \mathrm{M}$ dalam gelas beker $500 \mathrm{~mL}$ kemudian dipanaskan pada temperatur $85{ }^{\circ} \mathrm{C}$ selama 40 menit. Setelah itu didiamkan pada suhu kamar selama 1 jam dan disaring menggunakan penyaring vakum. Filtrat yang dihasilkan diukur $\mathrm{pH}$ nya menggunakan $\mathrm{pH}$ meter dan dinetralkan dengan ditambahkan $\mathrm{NaOH} 0,05$ M pada pH $6-7$ (Rombout dan Thibaut, 1986). Filtrat yang dihasilkan ditambahkan aquades sampai volume $500 \mathrm{~mL}$ untuk memperoleh ekstrak pektin dengan kadar $1 \%$.

\section{c. Pembuatan Media \\ Pertumbuhan Bacillus subtilis}

Untuk media pertumbuhan bakteri Bacillus subtilis dibuat menjadi dua macam, yaitu media padat dan media cair.

\section{1) Media Padat}

Media padat yang digunakan untuk regenerasi bakteri Bacillus subtilis adalah Nutrien Agar (NA), dibuat dengan menimbang 1,15 gr serbuk NA (Criterion) kemudian dilarutkan dengan $50 \mathrm{~mL}$ aquades dalam erlenmeyer $100 \mathrm{~mL}$, kemudian campuran tersebut dipanaskan menggunakan hot plate hingga larutan terhomogenkan dengan disertai pengadukan, setelah itu didinginkan pada suhu ruang. Diukur $\mathrm{pH}$ larutan dengan menggunakan $\mathrm{pH}$ meter dan dinetralkan pada $\mathrm{pH} 6-7$ dengan ditambahkan $\mathrm{NaOH} 0,05 \mathrm{M}$ atau $\mathrm{HCl}$ 0,05 M. Larutan kemudian dituangkan pada 5 tabung reaksi, masing-masing tabung reaksi diisi 5 mL NA, setelah itu ditutup dengan kapas. Masing-masing tabung reaksi yang berisi NA disterilisasi dengan menggunakan autoklaf selama 15 menit pada temperatur $121{ }^{\circ} \mathrm{C}$, sebelum dimasukkan pada autoklaf tabung reaksi yang berisi media NA dimasukkan terlebih dahulu pada kantong palstik tahan panas. Setelah dilakukan sterilisasi selanjutnya tabung reaksi yang berisi media NA dimiringkan pada suhu ruang sampai memadat untuk memperoleh media agar miring (Putra, S. R. Dan Yuneta, R. 2009).

\section{2) Media Cair}

Media cair yang digunakan sebagi inokulum adalah Nutrien Borth (NB). Cara membuat media $\mathrm{NB}$, yaitu dengan menimbang 0,45 gr dari serbuk NB (Criterion) kemudian dilarutkan dengan $50 \mathrm{~mL}$ aquades. Larutan tersebut dihomogenkan dengan dilakukan pemanasan menggunakan hot plate dengan disertai pengadukan, setelah itu larutan didinginkan pada suhu ruang. $\mathrm{pH}$ larutan diukur menggunakan $\mathrm{pH}$ meter dan dinetralkan pada $\mathrm{pH} 6-7$ dengan ditambahkan $\mathrm{NaOH} 0,05 \mathrm{M}$ atau $\mathrm{HCl}$ 0,05 M. Diambil $15 \mathrm{~mL}$ media NB 
Hidrolisis Gugus Metoksil Pektin Ampas Tebu Untuk ...

dan dimasukkan dalam erlenmeyer $100 \mathrm{~mL}$ yang selanjutnya digunakan untuk inokulum pembuatan kurva pertumbuhan dan sisa dimasukkan dalam erlenmeyer $100 \mathrm{~mL}$ yang selanjutnya digunakan untuk inokulum produksi ekstrak kasar enzim PMEs, kemudian masingmasing larutan dalam erlenmeyer ditutup dengan kapas. Media NB selanjutnya disterilisasi menggunakan autoklaf selama 15 menit pada temperatur $121{ }^{\circ} \mathrm{C}$, sebelum dimasukkan dalam autoklaf erlenmeyer yang berisi NB tersebut dimasukkan dalam kantong palstik tahan panas (Putra, S. R. Dan Yuneta, R. 2009).

\section{Media Produksi}

Media produksi yang digunakan untuk produksi ekstrak kasar enzim pektin metil esterase (PMEs) adalah media cair NB dengan campuran pektin $1 \%$. Cara membuat media NB dengan pektin $1 \%$ yaitu melarutkan 4,5 gr serbuk NB (Criterion) dilarutkan dengan $500 \mathrm{~mL}$ larutan pektin $1 \%$ dalam gelas beaker 500 $\mathrm{mL}$. Campuran tersebut dihogenkan dengan disertai pemanasan menggunakan hot palte dan disertai sedikit pengadukan untuk memperoleh larutan homogen, setelah itu didinginkan pada suhu ruang. Diukur $\mathrm{pH}$ larutan menggunakan $\mathrm{pH}$ meter dan dinetralkan pada $\mathrm{pH} 6-7$ dengan ditambahkan $\mathrm{NaOH} 0,05 \mathrm{M}$ atau $\mathrm{HCl}$ $0,05 \mathrm{M}$. Media cair NB pektin $1 \%$ hasil preparasi dimasukkan dalam 2 erlenmeyer $250 \mathrm{~mL}$, masing-masing erlenmeyer diisi dengan $150 \mathrm{~mL}$ media NB pektin $1 \%$ untuk produksi enzim kasar PMEs dan selebihnya digunakan untuk pembuatan kurva pertumbuhan bakteri Bacillus subtilis, yaitu dengan dimasukkan dalam 12 erlenmeyer $100 \mathrm{~mL}$, masing-masing erlenmeyer diisi 10 $\mathrm{mL}$ media NB pektin $1 \%$. Setiap erlenmeyer yang berisi media NB pektin $1 \%$ ditutup dengan kapas, kemudian disterilisasi menggunakan autoklaf selama 15 menit pada temperatur $\quad 121 \quad{ }^{\circ} \mathrm{C}$, sebelum dimasukkan autoklaf terlebih dahulu erlenmeyer yang berisi media NB pektin $1 \%$ dimasukkan dalam plastik tahan panas (Putra, S. R. Dan Yuneta, R. 2009).

\section{Regenerasi Bacillus subtilis}

Regenerasi bakteri Bacillus subtilis dapat dilakukan dengan mengambil 2 ose bakteri Bacillus subtilis dari stok kemudian digoreskan pada 5 media padat NA dari hasil preparasi dan diinkubasi selama 1 × 24 jam pada temperatur $35{ }^{\circ} \mathrm{C}$ kemudian hasil peremajaan disimpan dalam almari es (Putra, S. R. dan Yuneta, R. 2009).

\section{Pembuatan Kurva Per- tumbuhan Bacillus subtilis pada Media Produksi}

Untuk pembuatan kurva pertumbuhan bakteri Bacillus subtilis pada media produksi harus melalui beberata tahapan, yaitu:

\section{a. Pembuatan Inokulum Bacillus subtilis}

Sebelum melakukan kultur bakteri, terlebih dahulu tahapan yang harus dilakukan adalah pembuatan inokulum untuk menghologkan usia bakteri. Cara membuat inokulum yaitu dengan mengambil 2 ose bakeri Bacillus subtilis dari regenerasi kemudian diinokulumkan pada 15 $\mathrm{mL}$ media NB hasil preparasi, selanjutnya diinkubasi dalam seker inkubator dengan kecepatan $120 \mathrm{rpm}$ dan temperatur $35{ }^{\circ} \mathrm{C}$ selama 13 jam untuk memperoleh pertumbuhan bakteri pada fase eksponensial, inokulum tersebut selanjutnya 
digunakan untuk starter pada pembuatan kurva pertumbuhan.

\section{b. Inkubasi Selama 24 Jam}

Setelah diperoleh inokulum bakteri Bacillus subtilis, selanjutnya untuk membuat kurva pertumbuhan harus dilakukan inkubasi bakteri dalam media produksi selama 24 jam, dimana setiap 2 jam sekali (waktu inkubasi 0, 2, 4, 6, 8, 9, 15, 18, 20, 22 dan 24 jam) dilakukan uji kekeruhan. Pembuatan kurva pertumbuhan dapat dilakukan dengan menginokulasi $10 \%$ inokulum dalam 12 erlenmeyer $100 \mathrm{~mL}$ yang berisis media produksi hasil preparasi. Setelah dilakukan proses inokulasi, dari masing-masing media dilakukan inkubasi selama 24 jam dalam seker inkubator dengan kecepatan $120 \mathrm{rpm}$ dan temperatur $35{ }^{\circ} \mathrm{C}$ (Putra, S. R. dan Yuneta, R. 2009). kemudian dilakukan uji kekeruhan setiap 2 jam sekali, yaitu pada inkubasi $0,2,4,6$, $8,9,15,18,20,22$ dan 24 jam menggunakan spektrofotometer UVVIS.

\section{Produksi Ekstrak Kasar Enzim Pektin Metil Esterase (PMEs)}

Untuk produksi ektrak kasar enzim pektin metil esterase (PMEs) dapat dilakukan dengan melalui tahapan-tahapan:

\section{a. Pembuatan Inokulum}

Inokulum dibuat dengan cara mengambil 2 ose bakeri Bacillus subtilis dari regenerasi kemudian diinokulumkan pada $50 \mathrm{~mL}$ media NB hasil preparasi, selanjutnya diinkubasi dalam seker inkubator dengan kecepatan $120 \mathrm{rpm}$ dan temperatur $35{ }^{\circ} \mathrm{C}$ selama 15 jam untuk memperoleh pertumbuhan bakteri pada fase eksponensial, inokulum tersebut selanjutnya digunakan untuk produksi ektrak kasar enzim PMEs.

\section{b. Inkubasi pada Fase Eksponensial \\ Setelah dibuat kurva} pertumbuhan dan diketahui fase eksponensial dari pertumbuhan bakteri Bacillus subtilis, dari data tersebut selanjutnya akan dibuat untuk inkubasi pada tahapan produksi ekstrak kasar enzim PMEs, dengan menginokulasi $10 \%$ bakteri inokulum pada media NB pektin $1 \%$ dalam 2 erlenmeyer $250 \mathrm{~mL}$, masing-masing erlenmeyer berisi $150 \mathrm{~mL}$ NB pektin $1 \%$ dari hasil preparasi, selanjutnya diinkubasi sampai fase ekponensial yang diperoleh dari hasil pembuatan kurva pertumbuhan pada. Setelah dilakukan inokulasi pada media produksi, selanjutnya media tersebut dimasukkan dalam shaker inkubator dengan kecepatan $120 \mathrm{rpm}$ dan temperatur $35^{\circ} \mathrm{C}$.

\section{Isolasi Ekstrak Kasar Enzim PMEs}

Enzim PMEs yang dihasilkan dari kultur Bacillus subtilis merupakan enzim intarseluler, yaitu enzim yang dihasilkan dari dalam sel suatu mikroorganisme, sehingga tahapan isolasinya dibutuhkan tahapan untuk pemecahan dinding sel dari mikroorganisme. Untuk pemecahan dinding sel dari Bacillus subtilis digunakan metode enzim litik, metode ini paling efektif pada bakteri gram positif dikarenakan dinding sel bakteri garam positif lebih banyak mengandung polisakarida jika dibandingkan dengan bakteri garam negatif.

Setelah melewati masa inkubasi untuk mendapatkan ekstrak kasar enzim PMEs dilakukan proses sentrifugasi pada kecepatan 5000 rpm selama 15 menit dan diambil supernatannya. Dikarenakan enzim PMEs yang dihasilkan dari bakteri 
Hidrolisis Gugus Metoksil Pektin Ampas Tebu Untuk ...

Bacillus subtilis merupakan enzim yang dihasilkan secara intraseluler sehingga harus dilakukan tahapan pemecahan dinding sel bakteri pada pasta (pelet) hasil dari proses sentrifugasi.

Pemecahan mengunakan metode agitasi dengan abrasi, yaitu pasta (pelet) hasil dari sentrifus dibekukan selama 24 jam kemudian diletakkan dalam wadah yang mengandung butiran-butiran gelas dan ditumbuk dengan mortar dangan ditambahkan tiga kali dari volume pasta larutan buffer fosfat $0,1 \mathrm{M} \mathrm{pH} 7$ setelah itu diambil supernatannya menggunkan sentrifius pada kecepatan 5000 rpm selama 15 menit. Timbulnya gaya gesek akibat gradien kecepatan oleh tumbukan antara butiran gelas dengan pasta mikroorganisme menyebabkan pecahnya sel yaitu dengan ditambahkan sedikit enzim lisozim pada pasta yang berfungsi untuk memecahkan ikatan $\beta-1,4$ glikosida dari polisakarida (asam muramat) penyusun dinding sel.

\section{Uji Konfirmasi Ekstrak Kasar Enzim PMEs}

Uji konfirmasi ekstrak kasar enzim PMEs dilakukan pada enzim hasil sentrifus sebelum dan sesudah dilakukan pemecahan dinding sel bakteri, tujuannya yaitu untuk membandingkan kemampuan dari kerja enzim PMEs. Uji konfirmasi ekstrak kasar enzim PMEs dapat dilakukan dengan cara mengambil 10 $\mathrm{mL}$ ekstrak kasar PMEs hasil dari kultur Bacillus subtilis, kemudian ditambahkan dalam $50 \mathrm{~mL}$ larutan $\mathrm{NaCl} 0,15 \quad \mathrm{M}$ yang mengandung pektin $1 \%$, setelah itu diinkubasi dalam incubator dengan temperatur $35{ }^{\circ} \mathrm{C}$ selama 24 jam. Setelah melewati waktu inkubasi selanjutnya aktifitas enzimatis dinonaktifkan dengan memanaskan pada air mendidih selama 10 menit (Mandhania, S., V. Jain dan S. P. Malhotra, 2010).

Untuk mengetahui adanya gugus karboksil secara kualitatif dari asam pektat (hasil pemutusan metoksil dari akatifitas enzim PMEs) dapat dilakukan dengan melakukan titrasi dari hasil aktifitas enzimatis dengan larutan $\mathrm{NaOH} \quad 0,02 \quad M$ dengan menambahkan 2 tetes indikator PP (penolptalein).

\section{Produksi Biometanol}

Untuk produksi biometanol disini yaitu proses hidrolisis menggunakan ekstrak kasar enzim PMEs yang dihasilkan pada tahapan sebelumnya. Pada tahapan produksi biometanol digunakan dua variasi, yaitu variasi kosentrasi ekstrak kasar enzim pektin metil esterase (PMEs) dan variasi lama waktu inkubasi.

\section{Variasi Kosentrasi Ekstrak Kasar Enzim PMEs}

Metode yang digunakan untuk produksi biometanol yaitu menggunakan metode fermentasi terendam (Submerged Fermentation), hampir $90 \%$ proses enzimatis menggunakan metode fermentasi terendam untuk memperoleh hasil yang optimum. Metode $\mathrm{SmF}$ dilakukan dengan cara, diambil 5 gr ampas tebu hasil preparasi dan 10 mL (10\%) ekstrak kasar enzim PMEs kemudian ditambahkan aquades sampai volume $100 \mathrm{~mL}$ dalam gelas beaker $500 \mathrm{ml}$. Larutan dibuat pada $\mathrm{pH} 6$ - 7, setelah itu ditutup dan diinkubasi selama 24 jam menggunakan inkubator pada temperatur $35{ }^{\circ} \mathrm{C}$. Setelah melewati waktu inkubasi diambil filtratnya dengan depisahkan menggunakan penyaring vakum. Perlakuan di atas diulangi untuk kosentrasi PMEs 15 $\%$ (15 mL), $20 \%(20 \mathrm{~mL})$ dan $25 \%$ $(25 \mathrm{~mL})$ dengan dilakukan 2 kali 
pengulangan untuk memperoleh data yang akurat dengan analisis menggunakan $\mathrm{KG}$ untuk mengetahui hasil biometanol optimum.

\section{Pemisahan Biometanol Dengan Metode Destilasi}

Adapun perlakuaan proses destilasi hasil hidrolisi ampas tebu dengan menggunakan destilator biasa, yaitu filtrat hasil dari proses hidrolisis dimasukkan dalam labu alas bulat pada destilator. Sampel didestilasi pada temperatur $100{ }^{\circ} \mathrm{C}$ sampai teruapkan semua atau tidak ada cairan yang menetes pada labu destilat, kemudian destilat hasil destilasi ditampung dalam erlenmeyer $100 \mathrm{~mL}$. Destilat yang dihasilkan dianalisis dengan menggunakan kromatografi gas (KG) untuk mengetahui kadar dari biometanol.

\section{Analisa Biometanol Dengan Kromatogafi Gas (KG)}

Analisa menggunakan Kromatografi Gas (KG) dapat digunakan untuk analisa secara kulitatif maupun kuantitatif. Dikarenakan menggunakan larutan standart secara eksternal, maka untuk analisa secara kualitatif yaitu dengan membandingkan $t_{R}$ puncak dari hasil kromatogram antara standart dan sampel. Sedangkan untuk analisa kuantitatif menggunakan metode kalibrasi pada persamaan garis linier $y=\mathrm{b}_{0} \cdot x+\mathrm{b}_{1}$ dengan $y=$ ratio dan $x$ $=$ sebagai $(\%)$ sampel yang mana $y$, $\mathrm{b}_{0}$ dan $\mathrm{b}_{1}$ diperoleh dari perhitungan kurva kalibrasi.

\section{PEMBAHASAN}

\section{Ekstraksi Pektin Ampas Tebu}

Ampas hasil preparasi yang bebas dari senyawa non-pektin selanjutnya digunakan untuk ekstraksi pektin. Menurut Stephen (1995) untuk ekstrak pektin dapat dilakukan dengan menggunakan pelarut air, senyawa kelat (amonium oksalat, natrium heksametaphospat, etilen diamina tetraasetat (EDTA) dan sikloheksana diamina tetraasetat (CDTA) ), asam dan alkali. Namun dari beberapa pelarut yang digunakan untuk ekstrak, pelarut asam panas adalah pelarut yang paling baik yang dapat mengekstrak pektin 59\% (Thibault, 1988; Rombouts, Thibault, 1986). Menurut Hoejgaard (2004), pektin merupakan asam poligalakturonat yangmengandung metil ester. Pektin diekstraksi secara komersial dari kulit buah jeruk dan apel dalam kondisi asam. Pada penelitian ini dilakukan dengan cara 10 gr ampas tebu hasil preparasi dengan ditambahkan $200 \mathrm{ml}$ larutan $\mathrm{HCl}$ $0,05 \mathrm{M}$ dalam beaker gelas $500 \mathrm{ml}$ kemudian dipanaskan pada temperatur $85{ }^{\circ} \mathrm{C}$ selama 40 menit. Setelah itu didiamkan pada suhu kamar selama 1 jam dan disaring menggunakan penyaring vakum. Filtrat yang dihasilkan diukur $\mathrm{pH}-$ nya menggunakan $\mathrm{pH}$ meter dan dinetralkan dengan ditambahkan $\mathrm{NaOH} 0,05 \mathrm{M}$ pada rentan $\mathrm{pH}$ 6-7 (Rombout dan Thibaut, 1986). Filtrat yang dihasilkan ditambahkan aquades sampai volume $500 \mathrm{~mL}$ untuk memperoleh ekstrak pektin dengan kadar 1\%. Mekanisme ekstraksi pektin menggunakan $\mathrm{HCl}$ didasarkan pada kemampuan senyawa asam yang bersifat polar untuk mengikat senyawa polar yang terdapat dalam pektin yaitu asam galakturonat, sehingga akan memaksimalkan pengambilan senyawa pektin dalam ampas tebu.

\section{Media Produksi Enzim Kasar} Pektin Metil Esterase (PMEs)

Media produksi digunakan untuk produksi enzim kasar pektin metil 
Hidrolisis Gugus Metoksil Pektin Ampas Tebu Untuk ...

esterase (PMEs). Dari hasil penelitian Mardhania dkk (2010) menunjukkan bahwa enzim PMEs yang dihasilkan dari jamur Aspergillus heteromorphus MTCC 9262 pada media Potato Dextrose Medium (PDM), Pektin Medium (PM), Pektin Minimum Medium (PMM) and Czapeck Dox Medium (CDM), yang memiliki aktivitas enzim PMEs tertinggi (213 unit) yaitu PMEs yang dihasikan dari media PM kemudian PDM. Sehingga untuk membuat media produksi enzim PMEs dari bakteri Bacillus subtilis dapat digunkan media cair NB dengan campuran pektin $1 \%$. Cara membuat media NB dengan pektin $1 \%$ yaitu melarutkan 4,5 gr serbuk NB Criterion dilarutkan dengan $500 \mathrm{~mL}$ larutan pektin $1 \%$ dalam gelas beker $500 \mathrm{~mL}$. Campuran tersebut dihomogenkan dengan disertai pemanasan menggunakan hot palte dan disertai sedikit pengadukan untuk memperoleh larutan homogen, setelah itu didinginkan pada suhu kamar. Diukur $\mathrm{pH}$ larutan menggunakan $\mathrm{pH}$ meter dan dinetralkan pada rentang $\mathrm{pH}$ 6-7 dengan ditambahkan $\mathrm{NaOH} 0,05 \mathrm{M}$ atau $\mathrm{HCl} 0,05 \mathrm{M}$. Media cair NB pektin $1 \%$ hasil preparasi dimasukkan dalam 2 erlenmeyer@ $150 \mathrm{~mL}$ untuk produksi enzim kasar PMEs dan selebihnya digunakan untuk membuat kurva pertumbuhan bakteri, yaitu dengan dimasukkan dalam 10 erlenmeyer@20 mL. Erlenmeyer yang berisi NB pektin $1 \%$ ditutup dengan kapas berlemak kemudian kertas dan diikat menggunakan karet gelang. Media NB pektin 1\% kemudian disterilisasi menggunakan autoklaf selama 15 menit pada $121{ }^{\circ} \mathrm{C}$, sebelum dimasukkan autoklaf terlebih dahulu erlenmeyer yang berisi media NB pektin $1 \%$ dimasukkan dalam plastik tahan panas (Putra, S. R. Dan Yuneta, R. 2009).

Pektin yang dibuat untuk media produksi dapat diperoleh dari ekstrak ampas tebu maupun serbuk pektin beli jadi. Untuk membuat $150 \mathrm{~mL}$ media produk dari serbuk pektin dapat dilakukan dengan melarutkan 1,35 gr serbuk NB Criterion dalam $150 \mathrm{~mL}$ aquades, kemudian ditambahkahkan 1,5 gr serbuk pektin. Untuk menghomogenkan campuran tersebut dapat dilakukan dengan pemanasan menggunakan hot plate sampai campuran terhomogenkan, kemudian media ditutup dan disterilisasi menggunakan autoklaf pada temperatur $121{ }^{\circ} \mathrm{C}$ selama 15 menit. Gambar A merupakan media produksi NB pektin $1 \%$ dari serbuk pektin, sedangkan gambar $B$ merupakan media produksi NB pektin 1\% dari pektin ekstrak ampas tebu. Dapat disimpulkan dari warna yang nampak (lebih coklat) bahwa media dari ekstrak pektin ampas tebu lebih banyak mengandung pektinnya dengan berat yang sama.

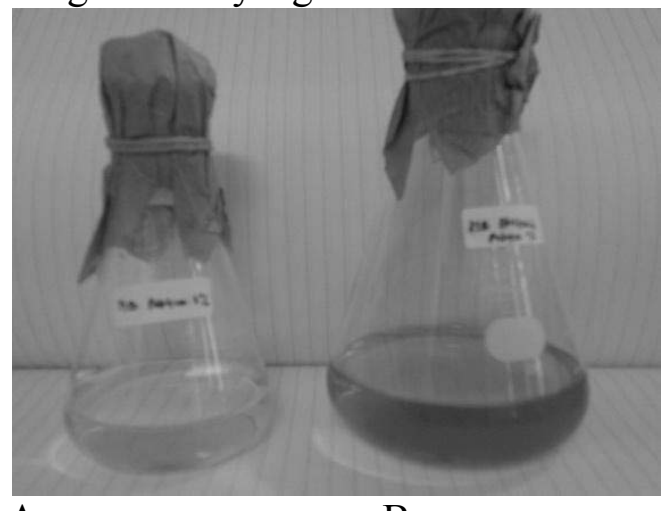

A B

\section{Peremajaan Bacillus subtilis}

Peremajaan bakteri dapat dilakukan dengan mengambil 2 ose bakteri Bacillus subtilis dari stok kemudian digoreskan pada media padat NA dari hasil preparasi dan 
diinkubasi selama 24 jam pada temperatur (Putra, S. R. dan Yuneta, R. 2009).

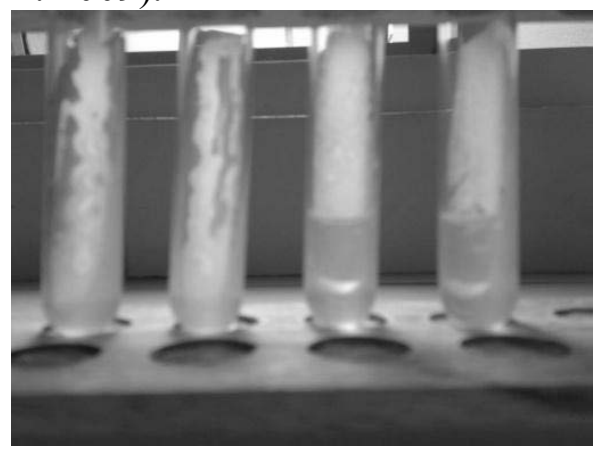

Nampak pada gambar diatas kultur dari bakteri Bacillus subtilis yang ditumbuhkan pada media padat agar miring dalam tabung reaksi. Meskipun tidak menunjukkan koloni Bacillus subtilis secara detail, sudah bisa dipastikan bahwa kultur tersebut benar-benar Bacillus subtilis yang secara umum kulturnya berwarna putih agak lembek.

\section{Pembuatan Starter/Inokulum Bacillus subtilis}

Starter/inokulum dapat dibuat dengan mengambil 2 ose bakeri Bacillus subtilis dari stok kemudian ditumbuhkan pada $50 \mathrm{~mL}$ media NB hasil preparasi, selanjutnya diinkubasi dalam shaker incubator dengan kecepatan $120 \mathrm{rpm}$ dan temperatur $35{ }^{\circ} \mathrm{C}$ selama 13 jam untuk memperoleh pertumbuhan bakteri pada fase lag, inokulum tersebut selanjutnya digunakan untuk starter pada pembuatan kurva pertumbuhan dan produksi ekstrak kasar enzim PMEs. Inkubasi selama 13 jam didasarkan pada penelitian Kosim dan Putra (2009) yang menyatakan fase $\log$ Bacillus subtilis dimulai pada jam ke-5 sampai jam ke-13.

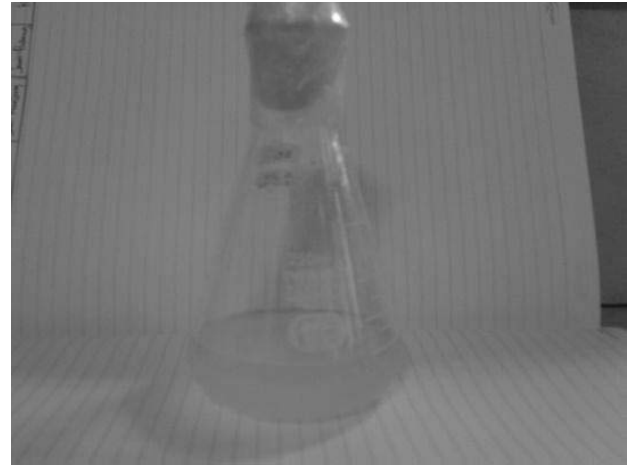

Gambar . Starter/ Inokulum Bacillus subtilis

5. Kurva Pertumbuhan Bacillus subtilis Pada Media Produksi

Kurva pertumbuhan dapat dilakukan dengan uji OD (optikal density) dari hasil kultur pada media produksi dengan dilakukan analisis setiap 2 jam sekali selama 24 jam (waktu inkubasi $0,2,4,6,8,9,15$, 18, 20, 22 dan 24 jam), yaitu dengan menginokulasi $10 \%$ bakteri Bacillus subtilis hasil biakan (starter) pada 20 $\mathrm{mL}$ media NB pektin $1 \%$ dalam erlenmeyer $100 \mathrm{~mL}$, selanjutnya diinkubasi dalam shaker incubator dengan kecepatan 120 rpm dan temperatur $35{ }^{\circ} \mathrm{C}$ (Putra, S. R. dan Yuneta, R. 2009).

Setelah dilakukan inkubasi 0,2 , $4,6,8,9,15,18,20,22$ dan 24 jam masing-masing biakan diambil 5-7 $\mathrm{mL}$ dan dimasukkan dalam tabung reaksi kemudian divortek sampai homogen. Larutan kemudian dimasukkan dalam kuvet dan diukur absorbansinya menggunakan spektronik 20+ pada panjang gelombang 600 nm.Data absorbansi Kurva pertumbuhan Bacillus subtilis

\begin{tabular}{|l|l|l|}
\hline No & Inkubasi (jam) & Absorbansi $(\lambda)$ \\
\hline 1 & 0 & 0,04 \\
\hline 2 & 2 & 0,18 \\
\hline 3 & 4 & 0,34 \\
\hline 4 & 6 & 0,47 \\
\hline 5 & 8 & 0,51 \\
\hline 6 & 15 & 0,58 \\
\hline 7 & 18 & 0,57 \\
\hline 8 & 20 & 0,57 \\
\hline 9 & 22 & 0,57 \\
\hline 10 & 24 & 0,57 \\
\hline
\end{tabular}


Hidrolisis Gugus Metoksil Pektin Ampas Tebu Untuk ...

Dari masing-masing waktu inkubasi dibuat kurva pertumbuhan dengan regresi hubungan garis $\mathrm{X}$ (absorbansi) dan $\mathrm{Y}$ (waktu inkubasi) untuk mengetahui fasefase pertumbuhan dari Bacillus subtilis pada media NB pektin $1 \%$ untuk produksi ekstrak enzim kasar PMEs.

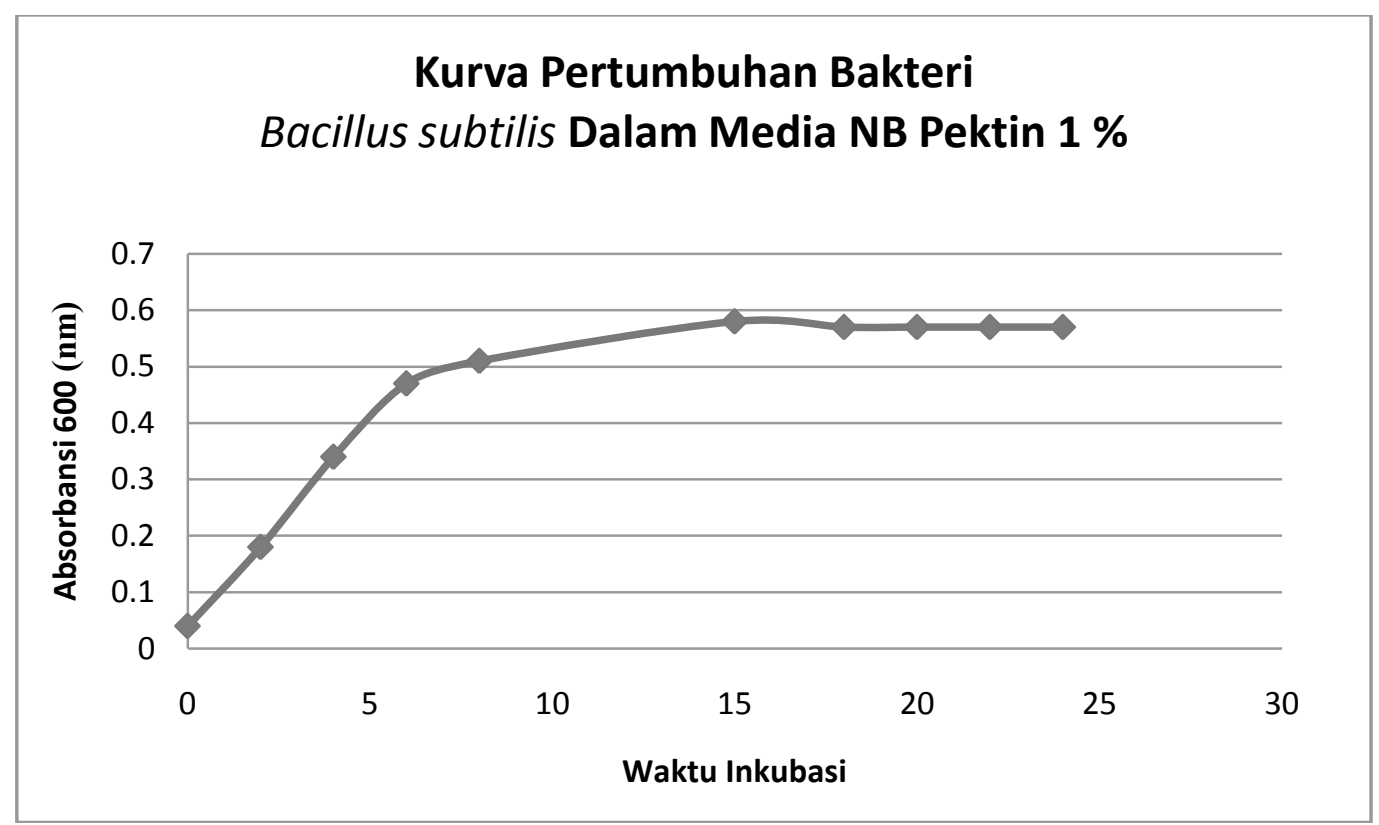

Kurva Pertumbuhan Bacillus subtilis

Kurva pertumbuhan diperoleh dengan metode turbidimetri, yaitu melihat jumlah bakteri dengan mengukur densitas optik pada panjang gelombang $600 \mathrm{~nm}\left(\mathrm{DO}_{600}\right)$ sebagai fungsi waktu dimana pengukuran dilakukan selama 24 jam dengan selang waktu 2 jam. Prinsip dasar metoda turbidimetri adalah, jika cahaya mengenai sel, maka cahaya dipantulkan dan cahaya yang tidak mengenai sel akan diteruskan. Jumlah cahaya yang diteruskan proporsional (berbanding lurus) dengan transmitan, sedangkan cahaya yang dipantulkan berbanding terbalik dengan transmitan atau berbanding lurus dengan absorbansi.

Dari kurva pertumbuhan Bacillus subtilis pada Gambar diatas, dapat dilihat bahwa Bacillus subtilis melakukan adaptasi pada fase lag selama \pm 2 jam. Waktu adaptasi ini dapat dikatakan singkat. Hal ini dikarenakan media starter untuk pertumbuhan awal bakteri sama dengan media produksi, akibatnya usia sel relatif seragam atau homogen, karena transter ini hanya bertujuan untuk menghomologkan umur bakteri agar seragam. Setelah mengalami fase adaptasi, sel mulai membelah dengan kecepatan yang sangat rendah karena baru selesai tahap penyesuaian diri. Fase ini merupakan fase pertumbuhan awal.

Setelah mengalami fase adaptasi, maka bakteri akan memasuki fase $\log$. Fase $\log$ adalah fase dimana bakteri mengalami pertumbuhan yang sangat cepat, dan dapat dikatakan pada fase ini bakteri mengalami pertumbuhan eksponensial. Selain itu, kebutuhan akan energi bagi bakteri pada fase ini lebih tinggi dibandingkan pada fase lainnya. Oleh karena itu, pada fase 
ini bakteri banyak memproduksi zatzat metabolit yang dibutuhkan dalam memenuhi kebutuhan nutrisinya.

Pada penelitian ini, fase log bakteri terjadi pada jam ke-2 hingga jam ke15. Oleh karena itu dilakukan isolasi/ produksi ekstrak kasar enzim pektin metil esterase (PMEs) pada jam ke-8 sebagai pertengahan dari fase $\log$ bakteri.

Kerapatan optik menurun setelah jam kelimabelas. Pada fase ini bakteri mulai memasuki fase kematian. Kematian ini terjadi karena zat makanan yang diperlukan bakteri berkurang dan hasil ekskresi bakteri telah bertimbun dalam medium, sehingga menganggu pembiakan dan pertumbuhan bakteri selanjutnya.

\section{Produksi Ekstrak Kasar Enzim Pektin Metil Esterase (PMEs)}

Untuk produksi ekstrak kasar enzim pektin metil esterase (PMEs) dapat dilakukan dengan menginokulasi $10 \%$ bakteri starter pada media NB pektin $1 \%$ dalam 2 erlenmeyer250 mL@150 mL hasil preparasi, selanjutnya diinkubasi selama 8 jam pada shaker incubator dengan kecepatan $120 \mathrm{rpm}$ dan temperatur $35{ }^{\circ} \mathrm{C}$. Hasil produksi enzim PMEs dengan menggunakan media NB pektin 1\% dapat dilihat pada gambar dibawah ini, gambar A menggunakan media NB pektin $1 \%$ pektin hasil ekstrak, sedangkan gambar B menggunakan media NB pektin $1 \%$ pektin serbuk.

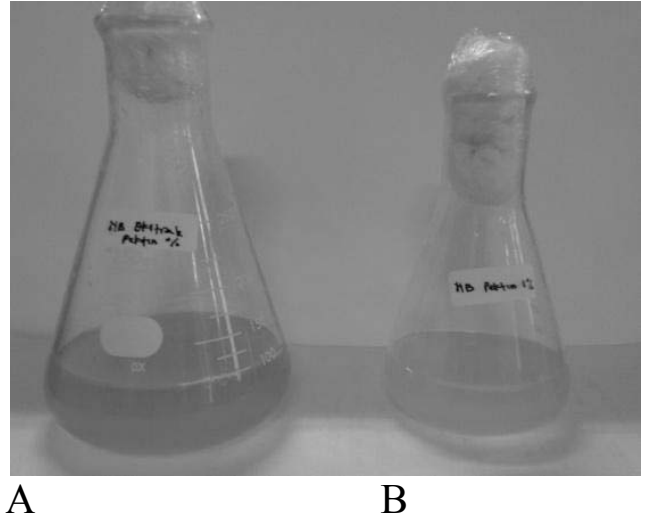

Setelah dilakukan inkubasi, untuk mengekstrak enzim kasar pektin metil esterase (PMEs) dapat dilakukan dengan mensentrifugasi hasil biakan dengan kecepatan 5000 rpm selama 30 menit dan temperatur $5{ }^{\circ} \mathrm{C}$. Selanjutnya dipisahkan antara filtrat dan endapan sel. Enzim kasar pektin metil esterase terdapat pada filtrat (merupakan enzim ekstraseluler), yang selanjutnya digunakan untuk proses hidrolisis ampas tebu menghasilkan metanol.

\section{Uji Konfirmasi Ekstrak Kasar Enzim Pektin Metil Esterase (PMEs)}

Uji konfirmasi ekstrak kasar enzim PMEs merupakan tahap untuk karakterisasi terhadap enzim kasar (PMEs) yang dihasilkan. Pada penelitian ini dapat dilakukan dengan cara mengambil $10 \mathrm{~mL}$ ekstrak kasar PMEs hasil dari kultur Bacillus subtilis pada media pektin hasil ekstrak, kemudian ditambahkan dalam $50 \mathrm{~mL}$ larutan $\mathrm{NaCl} 0,15 \mathrm{M}$ yang mengandung pektin $1 \%$. Gambar A larutan $\mathrm{NaCl} 0,15 \mathrm{M}$ pektin 1\% dari hasil ekstrak sedangkan B larutan $\mathrm{NaCl} 0,15 \mathrm{M}$ pektin $1 \%$ serbuk. 
Hidrolisis Gugus Metoksil Pektin Ampas Tebu Untuk ...

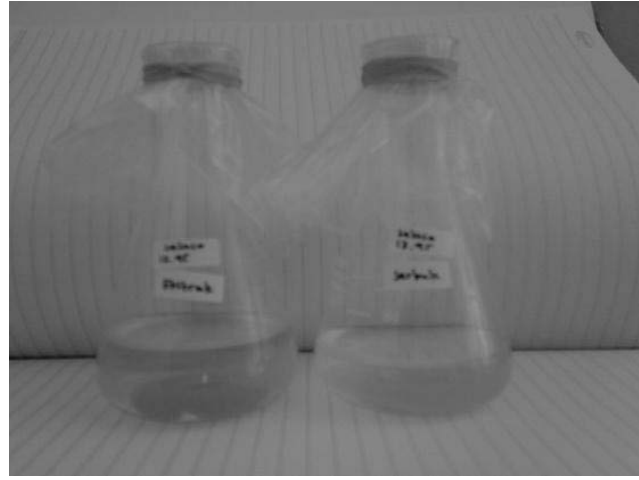

A B

Setelah itu diinkubasi dalam incubator dengan temperatur $35{ }^{\circ} \mathrm{C}$ selama 24 jam. Setelah melewati waktu inkubasi selanjutnya aktifitas enzimatis dinonaktifkan dengan memanaskan pada air mendidih selama 10 menit (Mandhania, S., V. Jain dan S. P. Malhotra, 2010).

Untuk mengetahui adanya gugus karboksil pada asam pektat (hasil pemutusan metoksil dari aktifitas enzim PMEs) dapat dilakukan dengan melakukan titrasi dari hasil aktifitas enzimatis dengan larutan $\mathrm{NaOH}$ 0,02 $\mathrm{M}$ dengan menambahkan 2 tetes indikator PP (penolptalein). Titrasi pada uji konfirmasi ini merupakan titrasi asam basa, dimana hasil yang kita inginkan adalah seberapa banyak $\mathrm{NaOH}$ yang dibutuhkan untuk menetralkan asam pektat dalam sampel yang selanjutnya dianalisis kadar metanol dengan GC yang merupakan hasil pemutusan metoksil dari aktifitas enzim PMEs.

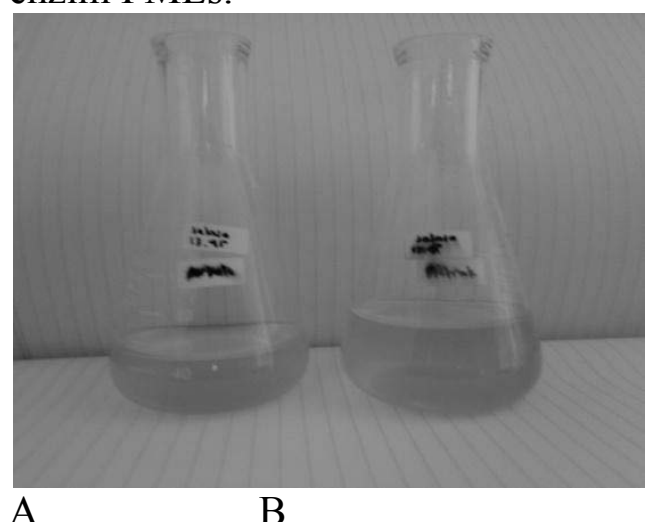

Volume titran $(\mathrm{NaOH} 0,02 \mathrm{M})$ untuk media pektin hasil ekstrak (gambar B) sebesar $8 \mathrm{~mL}$, sedangkan volume titran untuk media pektin serbuk (gambar A) sebesar $4 \mathrm{~mL}$. Dengan demikian aktifitas PMEs untuk memutuskan gugus metoksil asam galakturonat lebih besar pada media pektin hasil ekstraksi (B) sehingga metanol yang dihasilkan lebih besar, dan hasil dari analisis kadar metanol menggunakan GC adalah 0,12 \% dengan hasil samping etanol sebesar $0,02 \%$. Perhitungan dan data hasil dari GC ada di lampiran 1.

\section{Produksi \\ Biometanol}

(Hidrolisis oleh PMEs) dengan Variasi Kosentrasi Ekstrak Kasar Enzim Pektin Metil Esterase (PMEs)

Metode yang digunakan untuk produksi biometanol yaitu menggunakan metode $\mathrm{SmF}$ (Submerged Fermentation), hampir $90 \%$ proses enzimatis menggunakan metode SmF untuk memperoleh hasil yang optimum. Metode $\mathrm{SmF}$ dilakukan dengan cara, diambil 10 gr ampas tebu hasil preparasi kemudian ditambahkan $200 \mathrm{ml}$ aquades, dengan dicampur 10\% ekstrak kasar enzim PMEs $(20 \mathrm{ml})$ dalam beaker glass $500 \mathrm{ml}$ setelah itu ditutup dan diinkubasi menggunakan inkubator pada temperatur $35{ }^{\circ} \mathrm{C}$. Setelah melewati waktu inkubasi (24 jam) diambil filtratnya dengan dipisahkan menggunakan penyaring vakum. Perlakuan diatas diulangi untuk konsentrasi PMEs yang lain yaitu: $15 \%(30 \mathrm{~mL}), 20 \%(40 \mathrm{~mL})$ dan $25 \%(50 \mathrm{~mL})$ dengan pengulangan 2 kali.

\section{Analisis Kadar Biometanol}

Analisis menggunakan

Kromatografi Gas (KG) dapat digunakan untuk analisa secara kulitatif maupun kuantitatif. Untuk 
analisa kadar biometanol (kuantitatif) dikarenakan menggunakan kurva kalibrasi standart internal maka sampel juga ditambahkan larutan pembanding asam propionat dengan komposisi yang hampir sama dengan larutan sandart. Sampel diinjeksikan sebnyak $1 \mu \mathrm{gr}$ dalam inlet kemudian dilakukan runing menggunakan $\mathrm{KG}$ yang sudah dipreparasi untuk menghasilkan kromatogram.

Untuk mengetahui kadar biometanol dari sampel, langkah prtama yang harus dilakukan yaitu mencari peak dari hasil kromatogram yang memiliki $t_{R}$ (waktu retensi) metanol yaitu antara $3-4$, setelah ditemukan peak dengan $t_{R}$ metanol (3 - 4) kemudian dianalisa menggunakan metode kalibrasi pada persamaan garis linier $y=\mathrm{b}_{0} \cdot x+\mathrm{b}_{1}$ dengan $y=$ ratio area sampel (metanol) dan $x=$ sebagai kadar (\%) sampel yang mana $y, b_{0}$ dan $b_{1}$ diperoleh dari perhitungan kurva kalibrasi.

Hasil analisis kadar metanol dengan variasi konsentrasi

\begin{tabular}{|c|c|c|}
\hline Variasi Konsentrasi & \multicolumn{2}{|c|}{ Kadar methanol (\%) } \\
\cline { 2 - 3 } PMEs (\%) & $\begin{array}{c}\text { Ulangan } \\
1\end{array}$ & $\begin{array}{c}\text { Ulangan } \\
2\end{array}$ \\
\hline 10 & 0,02 & 0 \\
\hline 15 & 0 & 0 \\
\hline 20 & 0 & 0 \\
\hline 25 & 0 & 0 \\
\hline
\end{tabular}

Dari hasil analisa kadar biometanol menggunakan intrumen $\mathrm{KG}$ dan kromatogram yang dihasilkan (lampiran 2), pada konsentrasi PMEs 10\% terdapat kadar metanol sebesar $0,02 \%$ dan pada ulangan ke-2 dan pada konsentrasi yang lain ternyata pada kromatogram tidak ditemukan peak dengan $t_{R}$ metanol $(3-4)$, dengan demikian eksperimen kali ini gagal. Kegagalan tersebut dimungkinkan karena ampas yang digunakan terlalu lama sehingga dapat merusak kandungan selulosa ampas tebu, secara tidak langsung gugus metoksil pada pektin ampas tebu akan berkurang, sehingga proses hidrolisis gugus metoksil pektin ampas tebu menggunakan enzim PMEs tidak bekerja secara maksimal untuk menghasilkan metanol.

\section{KESIMPULAN DAN SARAN 1. Kesimpulan}

Pada penelitian ini dapat disimpulkan konsentrasi yang memungkinkan digunakan untuk hidrolisis ampas tebu untuk menghasilkan metanol dengan menggunakan enzim kasar PMEs dari Bacillus subtilis adalah 10\% dengan kadar metanol 0,02\%.

\section{Saran}

Pada penelitian ini masih belum dihasilkan metanol yang optimal, ada beberapa kemungkinan yang menyebabkan hal tersebut terjadi, yaitu :

a. Ampas tebu yang rusak selama penyimpanan.

Sebaiknya menggunakan ampas tebu yang masih baru dari limbah pembuatan gula.

b. Penggunaan waktu untuk produksi PMEs tidak sesuai dengan fase log kurva pertumbuhan Bacillus subtilis yang seharusnya 8 jam, tapi dilakukan pada waktu 24 jam. Sehingga kemungkinan PMEs yang dihasilkan sedikit sehingga tidak bekerja secara optimal untuk menghasilkan metanol. Sebaiknya produksi PMEs sesuai fase log dari Bacillus subtilis.

\section{E. UCAPAN TERIMAKASIH}

Penulis mengucapkan terima kasih kepada Lembaga penelitian dan pengembangan UIN maliki 
Hidrolisis Gugus Metoksil Pektin Ampas Tebu Untuk ...

Malang yang telah mendanai penelitian ini.

\section{F. DAFTAR PUSTAKA}

Abulyasa. 2009. Pra-rancangan Pabrik Methanol Dari Gas Sintesis Kapasitas 60.000 ton/tahun. http: //www. prarancangan-pabrik-methanoldari-gas.html. Diakses tanggal 22 Agustus 2011.

Ahlawat, S., S.S. Dhiman, B. Battan, R.P. Mandhan dan J. Sharma. 2009. Pectinase production by Bacillus subtilis and its potential application in biopreparation of cotton and micropoly fabric. Process Biochem. 44: 521-526.

Anonimous. 2005. U.S. Departemen of Energi. Available at http://www.eere.energy.gov/biom ass/. Diakses tanggal 23 April 2011.

Anonimous. 2007. Tanaman TebuSugar Cane.

http://anekaplanta.wordpress.co $m$. Diakses tanggal 19 juli 2010.

Anonimous. 2010 a . Laporan Market Intelligence Industri Methanol Di Indonesia. http: $/ / w w w$. Gasalam2010Methanol.html.

Diakses tanggal 22 Agustus 2011.

Anonimous. 2011' . Protokol Kyoto dan Aplikasinya. http: //www Alu thecocolathe.htm. Diakses tanggal 17 Maret 2011.

Anwar, S. 2008. Ampas Tebu. http: //www Let's START. htm. Diakses tanggal 28 Maret 2011.

Ardiansyah, Y.T. 2009. Isolasi dan Karakterisasi Enzim Xilanase dari Bacillus subtilis pada Media Nutrien Broth dengan Penambahan Xilan Hasil Isolasi Jerami Padi. Skripsi Tidak Diterbitkan, Jurusan Kimia,
Fakultas MIPA, Universitas Diponegoro Semarang.

Bhat, M.K. 2000. Cellulases and related enzymes in biotechnology. Biotechnol. Adv. 18: 355-383.

Cao, J., L. Zheng dan S. Chen. 1992. Screening of pectinase producer from alkalophilic bacteria and study on its potential application in degumming of ramie. Enzyme Microbial Technol, 14: 10131016.

Cheng, J. J. dan Timilsina, G. R. 2010. Advenced Biofuel Technologies Status and Barriers. Policy Research Working Paper, 5411.

Constenla, D. dan J.E. Lozano. 2003. Kinetic Model of Pektin Demethylation. Latin American Applied Research 33:91-96.

Cornick, N.A., N.S. Jensen, D.A. Stahl, P.A. Hartman dan M.J. Allison. 1994. Lachnospira pectinoschiza sp. nov., an anaerobic pectinophile from the pig intestine. Int. J. Syst. Bacteriol, 44: 87-93.

Dwidjoseputro. 2005. Dasar-Dasar Mikrobiologi. Jakarta: Djambatan.

El-Sheekh, M.M., A.S. Ismail, M.A. El-Ab, E.M. Hegazy dan A.I. ElDiwany. 2009. Effective technological pectinases by Aspergillus carneus NRC1 utilizing the Egyptian orange juice industry scraps. Int. Biodeterioration Biodegradation, 63: 12-18.

Fawole, O.B. dan S.A. Odunfa. 2003. Some factors affecting production of pectic enzymes by Aspergillus niger. Int. Biodeterioration Biodegradation, 52: 223-227. 
Forster, H. 1988. Pectinesterase from Phytophthora infestans. Methods Enzymol, 161: 355-357.

Gainvors, A., V. Frezier, H. Lemaresquier, C. Lequart, M. Aigle dan A. Belarbi. 1994. Detection of polygalacturonase, pectin lyase and pectinesterase activities in Saccharomyces cerevisiae strain. Yeast, 10: 1311-1319.

Galiotou-Panayotou, M.P.R. dan M. Kapantai. 1993. Enhanced polygalacturonase production by Aspergillus niger NRRL-364 grown on supplemented citrus pectin. Lett. Applied Microbiol., 17: 145-148.

Gandjar, I. Sjamsuridzal, W dan Oetari, A. 2006. Mikrobiologi: Dasar dan Terapan. Jakarta: Yayasan Obor Indonesia.

Ghildyal, N.P., S.V. Ramakrishna, P. Nirmala, B.K. Devi dan H.A. Asthana. 1981. Large scale production of pectolytic enzyme by solid state fermentation. Food Sci. Technol., 18: 243-251.

Gummadi, S.N. dan T. Panda. 2003. Purification and biochemical properties of microbial pectinases: A review. Process Biochem, 38: 987-996.

Hadj-Taieb, N, M. Ayadi, S. Trigui, F. Bouabdollah dan A. Gargouri. 2002. Hyper production of pectinase activities by fully constitutive mutant (CT 1) of Penicillium occitanis. Enzyme Microbial Technol, 30: 662-666.

Heikinheimo, R., Hemilia H., Pakkanea, R. dan Palva, I. 1990. Production of pektin mrthylesterase from Erwinia chrysanthemi. Applied Microbiology Biotechnology. 35: 51-55.
Hendayana, S. 2006, Kimia Pemisahan Metode Kromatografi dan Elektroforesis Modern, Bandung: PT. Remaja Rosdakarya.

Huang, Q. dan C. Allen, 1997. An exo-poly-a-D-galacturonosidase, Peh $\mathrm{B}$, is required for wild type virulence of Ralstonia solanacearum. J. Bacteriol, 179: 7369-7378.

Karam, N.E. dan A. Belarbi. 1995. Detection of polygalacturonase and pectinesterases in lactic acid bacteria. World J. Microbiol. Biotechnol, 11: 559-563.

Kashyap, D.R., P.K. Vohra, S. Chopra and R. Tewari. 2001. Applications of pectinases in the commercial sector: A review. Bioresour. Technol., 77: 215227.

Kawano, C.Y., M.A.S.C. Chellegatti, S. Said and M.J.V. Fonseca. 1999. Comparative study of intracellular and extracellular pectinases produced by Penicillium frequentans. Biotechnol. Applied Biochem, 29: 133-140.

Madigan M, Martinko J (editors). 2005. Brock Biology of Microorganisms (11th ed.). Prentice Hall. ISBN 0-13144329-1.

Mandhania, V. S. J., dan S.P. Malhotra. 2010. Culture Optimization for Enhanced Production of Microbial Pectin Methylesterase under Submerged Conditions. Asian J. Biochem., 5: 12-22.

Micheli, F. 2001. Pectin methylesterase: cell wall enzymes with important roles in plant physiology. Trends Plant Sci., 6: 414-419. 
Hidrolisis Gugus Metoksil Pektin Ampas Tebu Untuk ...

Murad, H.A dan Azzaz, H. 2011. Microba Pectinases and Ruminant Nutrion. Asian $J$. Biochem., 5: 12-22.

Ngili, Y. 2009. Biokimia Metabolisme \& Bioenergetika. Yogyakarta: Graha Ilmu.

Pandey, A., C.R. Soccol, J.A. Rodriguez-Leon dan P. Nigam. 2001. Solid-State Fermentation in Biotechnology: Fundamentals and Applications. 1st Edn., Asiatech Publishers Inc., New Delhi, ISBN: 81-87680-06-7, pp: 221.

Rombouts, F.M., dan Thibault, J.F. 1986. Sugar beet pectins: chemical structure and gelation through oxidative coupling. Chemistry and Function of Pectins. Washington, DC: American Chemical Society.

Rusbiantoro, D. 2008. Global Warming For Beginner. Yogyakarta: $\mathrm{O} 2$.

Saepudin, E. dan Setiasih, S. 2006. Kuliah Bioteknologi (Handout). Dep. Kimia, Fakultas MIPA-UI. Jakarta.

Sarvamangala, R.P. dan A. Dayanand. 2006. Production of pectinase from deseeded sunflower head by Aspergillus niger in submerged and solidstate conditions. Bioresour. Technol., 97: 2054-2058.

Satyawiharja, B. 1982. Production of Fungal Pectinases by Solid Fermentation Using Tapioca
Waste. MSc Thesis Tidak Diterbitkan. Univ. Mysore, India. Satyawiharja, B. 1992. Fermentasi Media Padat dan Manfaatnya. Dirjen Dikti, Dep. P dan K., Jakarta.

Schaechter, M., J.L. Ingraham, F.C. Neidhardt. 2006. Microbe. ASM Press, Washington, DC.

Setiyono, L. 2011. Bacillus subtilis dan Aplikasinya dalam Industri. http: //www. Blurry Eyes.htp. Diakses tanggal 7 April 2011.

Shoichi, T., K. Xoighi dan S. Hiroshi. 1985. Cellulase production by $P$. purpurogenum. J. Ferment. Technol., 62: 127127.

Thibault, J.F. 1988. Characterization and oxidative crosslinking of sugar-beet pectins extracted from cossettes and pulps under different conditions. Carbohydrate Polymers, 8, 209223.

Ujejski, L. 1957. The Detektor and Separation of Pektin Substances by Paper Chromatograpy and Paper Elektrophoresis. The Ohio Jurnal of Science, 57,212.

Wang, Q. 2006. Biometanol Conversion From Sugar Beet Pulp With Pektin Methyl Esterase. Tesis Tidak Diterbitkan. Faculty of the Graduate School of Maryland. College Park.

Winarno, F. G. 1986. Enzim Pangan. Jakarta: Gramedia. 